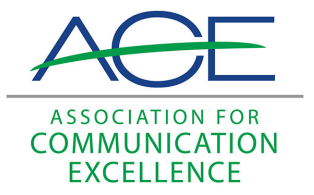

Journal of Applied Communications

\title{
Farmed and Dangerous? A Case Study of Chipotle's Branded Entertainment Series and Polarized Reactions to its Satirical Depiction of Farming and Agribusiness
}

\author{
Nathan Gikerson \\ Rebecca Swenson \\ Betsy Anderson
}

Follow this and additional works at: https://newprairiepress.org/jac (c) (i) (2)

This work is licensed under a Creative Commons Attribution-Noncommercial-Share Alike 3.0 License.

\section{Recommended Citation}

Gikerson, Nathan; Swenson, Rebecca; and Anderson, Betsy (2016) "Farmed and Dangerous? A Case Study of Chipotle's Branded Entertainment Series and Polarized Reactions to its Satirical Depiction of Farming and Agribusiness," Journal of Applied Communications: Vol. 100: Iss. 3. https://doi.org/10.4148/ 1051-0834.1234

This Research is brought to you for free and open access by New Prairie Press. It has been accepted for inclusion in Journal of Applied Communications by an authorized administrator of New Prairie Press. For more information, please contact cads@k-state.edu. 


\title{
Farmed and Dangerous? A Case Study of Chipotle's Branded Entertainment Series and Polarized Reactions to its Satirical Depiction of Farming and Agribusiness
}

\begin{abstract}
This study follows Chipotle's innovative strategy of using branded entertainment and satire to enhance its brand image and positive consumer perceptions, while negatively portraying an entire industry. The study explores audience reactions to Chipotle's satirical Farmed and Dangerous program, part of the company's broader "Food with Integrity" campaign. Increasing agricultural literacy and understanding among the general public is a priority (Doerfert, 2011). Yet marketing communication campaigns-and responses or reactions to those campaigns - that simplify issues into distinct "sides," or focus on attacks, prevent deep discussion of the complexity of our food system and efforts to collaborate on solutions. Research presented uses a case study, supported by focus group methodology and in-depth survey responses of YouTube commenters, to examine consumer and stakeholder reactions to Chipotle's content. Findings reveal sharply divided reactions and significant anger and frustration within the agricultural community toward Chipotle for its satirical portrayal of the food production industry. Findings also reveal generally positive attitudes toward Chipotle from those without agricultural experience, and clear perceptions of "sides" in the food debate. Discussion of Chipotle's marketing strategy explores whether the negative sentiment the company has generated among agricultural stakeholders through efforts like its Farmed and Dangerous webisode series is worth it for the brand, considering the broader positive image the company has gained among much of the general public, as well as related implications for the company linked to more recent struggles with food safety issues and attacks from political groups.
\end{abstract}

\section{Keywords}

Agriculture Communication, Branded Entertainment, Food Marketing, Public Relations, Satire, Sustainability 


\title{
Farmed and Dangerous? A Case Study of Chipotle's Branded Entertainment Series and Polarized Reactions to its Satirical Depiction of Farming and Agribusiness
}

\author{
Nathan Gikerson, Rebecca Swenson, and Betsy Anderson
}

\begin{abstract}
This study follows Chipotle's innovative strategy of using branded entertainment and satire to enhance its brand image and positive consumer perceptions, while negatively portraying an entire industry. The study explores audience reactions to Chipotle's satirical Farmed and Dangerous program, part of the company's broader "Food with Integrity" campaign. Increasing agricultural literacy and understanding among the general public is a priority (Doerfert, 2011). Yet marketing communication campaigns-and responses or reactions to those campaigns-that simplify issues into distinct "sides," or focus on attacks, prevent deep discussion of the complexity of our food system and efforts to collaborate on solutions. Research presented uses a case study, supported by focus group methodology and in-depth survey responses of YouTube commenters, to examine consumer and stakeholder reactions to Chipotle's content. Findings reveal sharply divided reactions and significant anger and frustration within the agricultural community toward Chipotle for its satirical portrayal of the food production industry. Findings also reveal generally positive attitudes toward Chipotle from those without agricultural experience, and clear perceptions of "sides" in the food debate. Discussion of Chipotle's marketing strategy explores whether the negative sentiment the company has generated among agricultural stakeholders through efforts like its Farmed and Dangerous webisode series is worth it for the brand, considering the broader positive image the company has gained among much of the general public, as well as related implications for the company linked to more recent struggles with food safety issues and attacks from political groups.
\end{abstract}

\section{KEY WORDS}

Agriculture Communication, Branded Entertainment, Food Marketing, Public Relations, Satire, Sustainability

\section{INTRODUCTION}

In 2014, the fast-casual food chain Chipotle released a four-part online "webisode" series titled Farmed and Dangerous. Through the free format, in which video content can be streamed online, Chipotle offered an entertaining storyline that unfolded over four, 20- to 23-minute episodes. While heavily marketed by the company through online advertising and promotional trailers, and in-store promotions such as branded soft drink cups (Chipotle Adverts, n.d.), the Chipotle brand itself was minimized in the satirical comedy program, only serving as an occasional backdrop in the narrative. Farmed and Dangerous is particularly interesting from a strategic communication perspective because the storyline lambasts the "Big Ag" industry, depicting the industrial farm business as alternatively depraved, money-hungry, and amoral. AdAge noted the clear message of Farmed and Dangerous: "Eat at Chipotle, because it doesn't have anything to do with that scary world" (Chipotle Hits, 2014, para. 2). 
Journal of Applied Communications, Vol. 100, Iss. 3 [2016], Art. 11

Chipotle received significant media coverage for this original branded entertainment, with advertising and public relations industry outlets enthusiastically touting the bold strategy behind the campaign (Nudd, 2014; Young, 2014). Not all viewers were receptive to the message, however, and farming communities in particular expressed outrage at Chipotle's vicious depiction of the industry. Outspoken members of the ag community accused Chipotle of using farmers as a punching bag to sell burritos, and news outlets covered Chipotle's controversial approach and the self-inflicted public relations challenge the company faced through its critique of and disassociation from industrial agriculture (Barrett, 2014; Doering, 2014).

This qualitative case study examines reactions to Chipotle's unique messaging strategy using a multi-method approach, including a series of focus group sessions and an in-depth survey of individuals who commented on Farmed and Dangerous on YouTube. Findings show strong evidence of polarized reactions to Chipotle's marketing and a clear perception of distinct "sides" in the food debate. Chipotle, it appears, alienated itself among some viewers, while strengthening its corporate image among others.

\section{History of Chipotle and Its "Food with Integrity" Campaign}

Founded in 1993 in Denver, Colorado, Chipotle Mexican Grill has grown rapidly to more than 1,600 locations in 43 states (Nath, 2015). Numerous articles have highlighted Chipotle's revenue growth as a publicly traded company (Munarriz, 2015; Solomon, 2014). Early expansion was partially supported through the McDonald's Corporation, which became a major investor in 1998, but partnership between the chains ended in 2006 when McDonald's fully divested itself from the burrito maker (Yohn, 2014). In recent years Chipotle's financial success-including a twenty-five percent profit margin on $\$ 2$ billion in sales in 2011 —has been the subject of food industry and business media articles (Nath, 2015; Yohn, 2014).

Chipotle's marketing has heavily emphasized its "Food with Integrity" campaign, which the company boasts on its website is a symbol of Chipotle's commitment to using ingredients "raised with respect for the animals, the environment and the farmers" (Chipotle Food, 2015, para. 1). Chipotle also claims that "whenever possible" its food includes meat that is free from antibiotics or added hormones, and that it sells organic and locally grown produce "when practical" (Chipotle Food, 2015, para 4). Emphasis on sustainable, organic and natural foods has resonated with many consumers, with annual sales growth over the past decade outperforming most competitors in its category (Nath, 2015). Growth, however, has also meant that Chipotle has not always been able to match its natural food rhetoric to its day-to-day business practices. Chipotle preemptively acknowledges this reality on its website: "We can't always purchase food from the little farmer down the road. In order to serve our customers, we sometimes work with larger farms and food distributors" (Chipotle People, 2015, para 2).

In January 2015, news outlets reported Chipotle would temporarily stop selling pork in one-third of its locations after discovering a supplier had violated the company's animal treatment policies (Peterson, 2015). Media reported quick resolution: Chipotle worked with other meat producers in its supply chain to purchase pork that met its animal treatment standards and returned the offering to its menus (Scherer, 2015). Although the crisis was short-lived, analysts noted the high-profile decision likely drove down revenue. Some predicted Chipotle's "natural" food sourcing policies would continue to be difficult to sustain long-term (Lutz, 2015).

During the fall of 2015, Chipotle faced a corporate crisis and associated drop in sales linked to a series of food safety issues. That November, the company temporarily closed restaurants in Oregon and Washington due to an extended E.coli outbreak that sickened dozens of customers (Fox, 2015). Weeks later approximately 140 people were sickened due to a norovirus outbreak linked to a Chipotle restaurant in Boston. The company attempted to address its sales and public relations crisis in December by taking out full-page ads in more than 60 major newspapers, featuring an apology from CEO Steve Ells, conveying remorse over customer illnesses and plans to implement improved food safety procedures (Trotter, 2015). But problems continued when Chipotle was served with a subpoena linked to a U.S. Attorney's 


\section{Gikerson et al.: Farmed and Dangerous? A Case Study of Chipotle's Branded Entertai}

Office investigation into yet another norovirus outbreak in California (Choi, 2016). In the aftermath of Chipotle's food safety scare, media questioned whether the company's "food with integrity" message would still resonate (Zarroli, 2016).

Recent company marketing efforts have relied heavily on highly negative portrayals of "big agriculture." In 2011 , the company released an animated YouTube video titled Back to the Start, which depicted the story of a family farmer who began to adopt industrial farming techniques, only to eventually realize these methods were harmful and unnecessary, and thus happily returned to simpler, more traditional farming. Two years later Chipotle released a second animated video called The Scarecrow, which told a similar tale about the harmful nature of industrial agriculture and the benefits of natural and traditional farming and food sourcing techniques. Scholars have examined the company's emphasis on sustainability and rejection of "Big Ag," noting that Chipotle's depictions of industrial food production cause audiences to think critically and draw natural conclusions that Chipotle's products are preferable and an obvious choice (Czaplewski, Olson, \& McNulty, 2014).

\section{Farmed and Dangerous}

In February of 2014, Chipotle escalated its criticism of the agricultural industry by launching the online satirical series Farmed and Dangerous. Featuring the program's three main characters-including a villain ominously holding a devil's pitchfork-and website described the show as, "A Chipotle original comedy series that explores the outrageously twisted and utterly unsustainable world of industrial agriculture" (Farmed and Dangerous, 2014, para 1). Farmed and Dangerous depicts the nefarious deeds of a fictional agribusiness company called Animoil, which aims to make billions of dollars selling a newly developed animal feed laced with oil (dubbed the "petropellet"), before being exposed and thwarted by a down-to-earth, likeable, free-range cattle farmer (named "Chip," presumably to represent Chipotle). The humorous series includes outrageous and preposterous moments, including an exploding cow and a bio-engineered, eight-winged chicken. The narrative is driven by a romance between Chip and the aggressive yet naive public relations "flack" for Animoil, who eventually realizes the evils of big agriculture and comes to value the sustainable food movement (Farmed and Dangerous, 2014).

Advertising industry press hailed Farmed and Dangerous as ambitious and a continued example of Chipotle's innovative marketing (Nudd, 2014). The series received a 2014 "Clio" award for Branded Entertainment and Content (Coloribus, 2015). In one article on the increasingly blurred line between "where brand marketing ends and Hollywood begins," Farmed and Dangerous was touted as an exemplar of the trend toward sponsored entertainment content for strategic public relations and marketing purposes (Stein, 2015, para.1).

\section{LITERATURE REVIEW}

\section{Branded Entertainment}

Chipotle's unique marketing efforts have been the subject of multiple academic studies within communication literature, including research examining the company's success in communicating "brand sincerity" and corporate social responsibility (Ragas \& Roberts, 2009), and research that holds up the company as an exemplar for studying the unique functions of brand attribute saliency among virtual brand communities (Ragas \& Roberts, 2009). Additionally, the company has frequently been discussed in the business press, often as a marketing innovator, with its use of branded entertainment content (Nudd, 2014; Stein, 2015). Growing use of branded entertainment as a sales and marketing strategy has also become the focus of academic research. Scholars have studied effects of branded entertainment as part of the broader "blurring of the lines" between entertainment content and persuasive marketing efforts (Shrum, 2012). Research has explored whether the tactic is indeed a "new" form of advertising, or just a more subtle and sophisticated form of product placement, a longtime strategy (Hudson \& Hudson, 2006), as well as the ability of branded entertainment on social media platforms to increase brand awareness and build consumer-brand relationships (Zhang, Sung, \& Lee, 2010).

\section{Satire as a Persuasive Messaging Tool}

Often described as a satirical comedy, Chipotle's Farmed and Dangerous series can also be explored in the context of a 
Journal of Applied Communications, Vol. 100, Iss. 3 [2016], Art. 11

growing body of literature examining satire as a persuasive messaging tool to illustrate weak or foolish qualities of another person or organization and to convey complex and ambiguous information. Research has examined the role of biased message processing in how viewers understand and interpret intended meaning of ambiguous political satire entertainment content, with findings suggesting that an individual's political ideology can influence the nature of biased processing (LaMarre, Landreville, \& Beam, 2009). Other research has examined the nature of different types of satirical content and its effectiveness as a tool for political persuasion (Holbert, Tchernev, Walther, Esralew, \& Benski 2013). Unique persuasive effects and the cognitive nature of how satire is processed have been the focus of recent studies (LaMarre, Landreville, Young, \& Gilkerson, 2014; Lee \& Kwak, 2014). Recent research focused on the documentary Food, Inc. explored how perceptions toward agriculture can be influenced by entertaining media content (Holt \& Cartmell, 2013).

\section{Political Consumerism and Online Activists}

Americans have been engaging in acts of political consumerism since the pre-revolutionary period with boycotts of British goods (Breen, 2005). Yet, scholars of corporate communication, political consumerism and online activism have typically focused on helping corporations respond to attacks from activist groups, rather than strategically launching the attacks themselves. Chipotle's decision to go on the offensive with Farmed and Dangerous is more aligned with activist strategies described by Spar and La Mure (2003) in their discussion of non-governmental organization (NGO) communication tactics than traditional corporate public relations strategies. Most scholars have focused on ways for corporations to build relationships with opposing groups and understand their concerns on a personal level (Veil et al, 2014).

\section{PURPOSE AND RESEARCH QUESTIONS}

Chipotle intentionally carved a niche within the competitive fast food industry, and created a distinctive brand based on opposition to conventional agriculture. Considering Chipotle's use of branded content and ambiguous messaging about agriculture embedded within satirical entertainment, this research examines the effectiveness of the company's approach and explores the range of consumer reactions to Farmed and Dangerous. In light of Chipotle's novel marketing strategy and the relevant academic literature, this study focused on three questions:

RQ1: What are participants' general perceptions of Chipotle?

RQ2: What messages did Chipotle's Farmed and Dangerous series convey about the company?

RQ3: How do viewers respond to Chipotle's marketing strategy?

\section{RESEARCH METHODS}

To address these questions, a multi-method case study approach was adopted. As argued by Yin (2013), the case study method allows for the study of complex and contemporary social phenomena in a real-life context-and is conducive to deploying multiple methods to search for converging findings from different data sources and the "triangulation" of evidence. This study combined focus groups and in-depth survey data to identify and validate common findings through consistent patterns of evidence, and to provide multiple levels of analysis (Yin, 2013). 


\section{Gikerson et al.: Farmed and Dangerous? A Case Study of Chipotle's Branded Entertai}

\section{Focus Groups}

During March 2014, three focus group sessions were conducted at three Midwestern universities. Following distribution of a research consent form, undergraduate participants were asked to describe Chipotle as a brand, including any "personality characteristics" they associated with the company. Participants then viewed the initial episode of Farmed and Dangerous. Participants wrote down their thoughts and reactions during and following the viewing of the program, including anything they might consider posting to social media.

Next participants were led in a guided discussion of the program and asked a set of questions about their perceptions of the program, the Chipotle brand, and the Farmed and Dangerous series. Focus groups ranged from 11 to 23 people, for a total of 47 participants. While a few had seen promotions for Farmed and Dangerous, the vast majority of focus group participants were either unaware of or had not seen the program. Two of the digitally recorded sessions were conducted with participants enrolled in a "Communication and Journalism" or "Strategic Communication" program, while the third was conducted with participants enrolled in a communication-focused course housed in the university's "Food, Agriculture and Natural Resources" program.

\section{In-Depth Online Survey}

Following Chipotle's February 2014 release of the Farmed and Dangerous series, a social media content tool called "NCapture" collected YouTube users' comments. Approximately 1,000 unique comments were captured during the twoweek period following the series launch. (Software used during the research limited collection to 1,000 online comments, and a small number of intelligible or non-human generated comments—i.e., "spambot posts" —were sorted for and removed.) Instead of conducting a content analysis of the social media posts, which would have limited perspective of users' thoughts and motivations, an in-depth qualitative survey of active commenters was developed to gain a more nuanced understanding of perceptions of Chipotle and its marketing.

Drawing from the original universe of 1,000 social media comments, comments were categorized by the number posted by each unique YouTube user. The online survey was distributed to users who had submitted multiple distinct comments related to Farmed and Dangerous, or who had engaged in multiple exchanges with other users who had also commented on the video. Using the user "contact" mechanism within YouTube, individual survey participation invitation emails were sent to each user's YouTube account, directing the individual to a research consent form and access to the online questionnaire. Participants were told the research "focused on the branding and marketing strategies used by food companies to promote sustainability and environmentalism," and that they would specifically be asked to answer questions about Chipotle's Farmed and Dangerous campaign. The survey was distributed and collected using a university-owned Qualtrics tool, and participant identifying information was not collected. An original total of 163 unique YouTube users who had commented on the video at least three times was identified, and survey invitations were sent to 150 users' accounts; those without no-contact restrictions on their YouTube accounts. In total, 13 individuals participated in the survey, for an $8.6 \%$ response rate.

\section{Data Analysis}

In analyzing data from both the transcribed focus group sessions and the open-ended survey responses, Strauss and Corbin's (1998) grounded theory approach to open coding was used. Participant comments were closely examined to identify various concepts and themes within the data, which were then grouped into general categories, and then, using an axial coding process, collapsed into categories representing significant themes and perspectives (Strauss \& Corbin, 1998). Key findings of this qualitative analysis process are presented below, along with selected illustrative quotes from participants. 


\section{FOCUS GROUP FINDINGS}

\section{General Perceptions of Chipotle}

Of the three focus group sessions conducted, two consisted of undergraduate students studying communication or strategic communication, while the third consisted of students with majors in the field of food production and agriculture. The most striking finding from these sessions was a stark contrast and polarization in attitudes about Chipotle and its marketing. Participants in the communication programs were neutral to overwhelmingly positive in their overall attitude toward Chipotle and, specifically, their response to viewing Farmed and Dangerous, while participants from the agriculture-focused program were almost unanimously negative in their views toward Chipotle and its broader marketing strategy.

\section{Perceived Messages and Viewer Reactions-Strategic Communication Focus Groups}

\section{Subtle and Effective Branding}

Among the communication program students, themes among participants' reactions related to the quality and effectiveness of the messaging strategy itself. One participant, representative of others in the group, commented that they thought the satirical entertainment format was "a good way to get audience engagement," and that the story's dramatic narrative would motivate them and others to seek the content online in order to "see what happens next." Another participant noted that Chipotle's marketing through Farmed and Dangerous was "very subtle" branding, and that it was going to be successful because Chipotle was "getting their name out there, but in a very secret way." While some participants reported that they thought the webisode was dramatic and entertaining, not all participants were laudatory of the satire's value as entertainment, with some expressing that they felt that the program and its narrative was "over the top," "extremely cheesy," or just "trying too hard."

Other participants commented that watching the webisode strengthened their already positive view toward Chipotle and the "higher quality" of the restaurant's food. Reflecting this idea, one person noted, "it kind of reaffirms my beliefs in Chipotle, because it is all organic and good..." while another participant said that what Chipotle was doing was creating "a really positive image for organic farms" and generally promoting the value of food.

\section{Genuine, Transparent, and Honest}

Multiple participants from the two communication student focus groups said that they felt the message from Farmed and Dangerous was that Chipotle was a "genuine," "transparent," "authentic," and "open and honest" company. One participant believed Chipotle's objective was to "tell the truth about the food industry." One participant argued that, "you could create something like this only if you were 100\% confident and transparent in your company," while another said that, with Chipotle's brand, "what you see is what you get," and that the Farmed and Dangerous program "shows they have nothing to hide." One participant noted that the title character, Chip, represented Chipotle and described him as "authentic" and "confident":

I also think you look at Chip and you think of him as an authentic, down to earth guy, which kind of goes with what Chipotle's trying to be. And it almost seems, how confident he is, is kind of like....and it might be a far stretch, but it might be Chipotle's confidence in their brand and their tactic of being organic, or being as organic as possible... and then obviously the other side...they're kind of scared right now and a little flustered.

This notion of "sides" in the food industry came up multiple times during the communication student focus groups. Participants argued that Chipotle's aim was to "educate" the public and position the company as a "good guy" within the system: 
In addition to it being educational, because I think that's a large part of it, I think they (Chipotle) are trying to distinguish themselves as a brand, like look, these are our values, and a lot of other companies are bad and people who want your money... so I think (their goal is) distinguishing themselves as the good guys.

Many participants from the communication student focus groups seemed to share this interpretation of Chipotle as a generally altruistic and sincere company, and a well-intentioned organization that was on the "right side" of the food debate.

However, one participant stood out and expressed strong negativity toward Chipotle and the Farmed and Dangerous webisode. Shown below, these comments contrasted with others in the group by conveying anger and describing Chipotle as "playing dirty":

I think in a way they're kind of playing dirty with this, and that made them look negatively about this, like the way the series was, instead of educating 'why it's good to be sustainable,' they're kind of in your face. 'I'm going to be really obnoxious about it,' and that made me view it very negatively. I actually come from a small family farm, so [the video] made me kind of angry, because some of the things, I believe, were false... what they were saying.

Notably, this was the only participant from the focus groups composed of communication students to indicate having a farming background. This participant discussed the complexity of the farming business and categorizations made within the agriculture industry, and a dislike of what they viewed as an oversimplification of types of farms and the notion of sustainability:

I don't like that they (Chipotle) put two sides, like there's either industrialization or there's sustainable, small family farms because I come from a 500-acre crop, dairy, and meat farm, so we do all three of them. It makes me frustrated that there are really small farms out there that can't afford to get the really good medicines, and they can't have enough space and stuff like that, so their cows might not be as healthy as a bigger farm that can, and that isn't necessary industrialized... they're just bigger, so they're viewed as industrialized, but that's false. So I think it should be paired, there can be sustainable while being industrialized. It's just, where's the line of being inhumane? That's the issue I think, that's my opinion.

\section{Perceived Messages and Viewer Reactions-Ag Communication Focus Group}

\section{Lack of Factual Information}

The tenor of the focus group discussion among students from the field of food production and agriculture was in stark contrast to the generally positive attitudes expressed toward Chipotle by members of the other focus groups. When asked about their initial reaction after viewing the Farmed and Dangerous, one agriculture student immediately described it as "ridiculous" and "frustrating." Criticizing the video, another argued that "there's no presentation of any facts..." and that the webisode didn't "actually define industrial agriculture, ever". Participants expressed frustration that Chipotle had, in their mind, misrepresented the entire agriculture industry:

I think that they're just negatively representing ag business in general. Like most consumers who see this are not going to be as educated as we are, and they don't understand the industry, and that they think.... They're (Chipotle) presenting that every company is unethical which is clearly not true. I think it's pretty wrong.

Focus group participants argued that Chipotle didn't understand the ag industry, and that its marketing efforts were harming everyone in agriculture. One participant said, "I don't think they're aware that bad publicity for conventional agriculture is bad publicity for all types of agriculture." Another added, "I also don't think they realize they're talking about family farms and being sustainable... I don't think they know what a family farm really is, if that is what they define as being sustainable." There was general agreement in the group that Chipotle and its marketers didn't really understand the industry. 


\section{Chipotle as Unethical, Hypocritical, Manipulative and Deceptive}

Many of the agriculture participants in the focus group discussed their feeling that Chipotle as a company was a "manipulative," "deceptive," or "hypocritical" organization. Conveying this perspective, one participant quipped, "I think it's funny that Chipotle is calling conventional agriculture manipulative, when they're being extremely manipulative the way they are trying to advertise." Participants discussed what they viewed as hypocrisy in Chipotle's harsh critiques of farming, noting that the company depends on the industry to produce the very food products that it sold:

I think that's part of where they're being extremely deceiving. I mean they're tearing down conventional agriculture, but they're feeding people products of conventional agriculture. That's kind of disappointing that they can't support the people that help their business.

The broader theme of Chipotle's hypocrisy came up many times during the focus group, with participants expressing a feeling of betrayal related to Chipotle's marketing:

Yeah, I was kinda surprised about like, how negative they (Chipotle) portrayed agriculture, since you know, they are an agriculture, you know, company, even though they may have like slightly different ways of feeding people. They're still agriculture, and to be making such a negative statement about, just like a slightly different sector of your own group, seems odd to me.

Participants felt Chipotle's depiction of the agriculture industry in Farmed and Dangerous was intentionally dishonest and deceptive. Discussing the satire, one participant argued, "... if you're going to do something like this, like, make sure that you're presenting it honestly and fairly."

Several participants discussed Chipotle's marketing rhetoric and stated devotion to organic and natural products, and how it conflicts with the company's regular use of conventionally raised food. One participant argued, "... without the conventional farmers, who they (Chipotle) get the food from, they wouldn't even have a business because they can't support themselves with their own principles or values," while another noted that they were aware that Chipotle's chicken products were sourced from "Gold N' Plump," a large poultry agribusiness.

\section{Being Attacked}

Many participants from the agriculture focus group described feeling that Chipotle was intentionally attacking farmers and "tearing down" people in agriculture in order to build its brand and boost sales. Discussing the negative depiction of agriculture in Farmed and Dangerous, one participant argued that Chipotle was not trustworthy:

In the video, they portray agriculturalists that would pretty much do anything to get to the top, anything to make a buck, which is like exactly what they're doing. They're tearing down everyone just to make their company better, they're hypocrites. They're saying other people tear each other apart, or like they'll do anything to make a buck, but that's exactly what they're doing. I don't know, they're hypocrites, trustworthy is the farthest thing from my mind.

Other participants said that Chipotle was only interested in profits and, despite the company's rhetoric about caring for and respecting farmers, its marketing was concerned solely with increasing sales. One participant from the agriculture group lamented that Chipotle's marketing meant that farmers were being forced to work harder to have a positive image in the public's mind: "It's just like tearing us down so that we have to work that much harder to make a positive image for agriculture in general." Another participant argued that Chipotle was proactively, "tearing down everybody else around them to try to get to the top." Expanding on this notion, the participant said, "...agriculture as an industry is trying to take two steps forward and Chipotle's pretty much dragging us two steps back." 


\section{Us Versus Them}

Many participants from the agriculture focus group had already formed a negative opinion of Chipotle from its previous marketing, in particular The Scarecrow video. Along with communicating that, as members of the agricultural community, they felt as though Chipotle was "attacking" them, participants also frequently conveyed an "us versus them". Expressing concern that viewers who were unfamiliar with the real world of agriculture would see Farmed and Dangerous and believe that it was more or less true, one participant commented that they were "outnumbered" in their conflict with Chipotle:

I just worry there's not enough of us, there's just so many people out there that don't even know a farmer and know an agriculturalist or someone out there who knows an agriculturalist, who will never have access to the real story that we have to tell, and so they're just going to see this and immediately believe it whole heartedly because they just don't know and it's unfortunate they don't have access to someone who will tell them the right story. That's a big problem because we are largely outnumbered.

Many participants conveyed a notion that the agriculture community was in an oppositional or antagonistic relationship with Chipotle. One participant mused that Chipotle's marketing efforts were "extremely innovative and smart on their end," and that they wished that the agriculture industry had some sort of sophisticated rebuttal message. One participant even said, "They have an excellent marketing team, no doubt about it."

Multiple participants described Chipotle as unnecessarily "ripping on" or "bashing" the agriculture industry. One comment focused on the company's CEO, and noted that the executive didn't have a background in agriculture, and didn't fully understand the issues:

So this guy (Chipotle's CEO), as far as I know, doesn't even have an education in agriculture at all, and I think that's part of where the problem stems from, like, he's not even in agriculture, so, as far as I know he hasn't taken the time to try and understand the industry that his company now is pretty much bashing.

Another participant was more thoughtful and reflective, and acknowledged that some of the issues within the agriculture industry that Chipotle was critiquing were indeed real problems, that needed fixing — but that Chipotle's superficial portrayal of the faults of the industry and demonization of big agriculture was not a way for those problems to be solved.

\section{Differences in Viewer Responses Linked to Affiliation with Agriculture}

Overall, focus group participants with backgrounds in agriculture seemed to view Chipotle, and its Farmed and Dangerous marketing, as opposing or threatening the ag industry-and something they needed to fight and overcome. One participant mentioned a personal boycott of Chipotle because of its treatment and depiction of farmers. Emphasizing the unfairness of Chipotle's depiction of agricultural workers, one participant emphatically stressed, "they're families that do this, and they're good people." Those participants with connections to agriculture held largely negative views toward the company, which they viewed as disingenuous and deceptive. None of these sentiments were expressed by members from the two general communication program focus groups, except for one participant who indicated a farming background. Instead discussion from the general focus groups conveyed nearly universally positive sentiment toward Chipotle, and focused on the sophistication of the company and its marketing, which were viewed as genuine, honest and ethical.

\section{ONLINE SURVEY FINDINGS}

As described earlier, this research also included an in-depth, open-ended, online survey of 13 unique users who had commented at least three or more times on the Chipotle Farmed and Dangerous YouTube page. This approach examined attitudes among individuals who demonstrated high engagement with the content and presumably strong-enough opinions of Chipotle and the webisode program to post comments. Analysis of the comments section showed that many of the single comments posted by YouTube users were predominately superficial. 
In examining findings, it was striking how similar many of the themes were to those found in the earlier focus group sessions. Some respondents' comments were generally very positive toward Chipotle and the messages of Farmed and Dangerous, while others were extremely critical of Chipotle's marketing efforts. Put another way, polarization in the different focus group reactions was also highly evident among survey respondents. While the survey did not explicitly ask participants to indicate whether they worked in the agriculture industry, or otherwise identified with farming or agriculture, it was evident through the content of the survey responses that many participants were part of, or strongly identified with, the agriculture community. Similar to findings with agriculture participants, many respondents seemed to have held a previous dislike of Chipotle's marketing strategy, and had posted to the YouTube comments section of Farmed and Dangerous to voice their displeasure with the company.

When asked during the survey what they believed to be the program's "main message," many responses conveyed anger and displeasure with how Chipotle depicted farmers, saying the goal was "to attack legitimate farmers and disparage them" or to tell audiences that "agriculture producers are unethical." One respondent boiled the program's message down: "Corporate ag is bad, Chipotle is good." Another survey respondent said Farmed and Dangerous was "Making agriculturists, those in the food system, and agribusiness people look like complete idiots... and based on the title, that farming is dangerous!"

Similar to the contrast in focus group sessions, however, other respondents conveyed sincere appreciation of Chipotle's message and agreement with the company's marketing strategies. Respondents indicated that message was, "That industrial farming isn't healthy and will eventually hurt us," and that "Big agriculture [is] hurting our economy and progress toward a sustainable and healthy future." One respondent connected Chipotle's message to broad environmental concerns like global warming and the planet's ecosystem:

Corporate food production and farming has negatively affected our planet - the ecosystem and the animals, plants and humans that inhabit our planet — and what we eat and drink all in the name of profits and supposed ultruistic (sic) aims to "feed the planet" and a growing, out-of-control population. It is this that is dangerous to our future, especially in the context of global warming.

Despite the presence of a few such positive comments, the majority of survey respondents were highly critical of Chipotle and the series, with one calling it "very misleading." Regarding a question about their perceived "relationship" with Chipotle and whether viewing Farmed and Dangerous had influenced their opinion of the company, one respondent wrote, "I already knew they were liars and based their marketing on fear." One respondent connected to agriculture succinctly made this argument: "All they do is lie. I have lived and breathed production agriculture and know their accusations to not be true." The two contrasting participants' comments shown below, which appeared next to each other in juxtaposition within the survey data, are perhaps most symbolic of the highly polarized reactions viewers had toward Chipotle's Farmed and Dangerous series, and the company's larger "Food with Integrity" campaign.

I hated Chipotle to begin with. I only hate them even more now. I will never eat there and also encourage everyone I come in contact with not to eat there. I liked them before. Now I like them more. :)

\section{DISCUSSION AND CONCLUSION}

The research presented shows evidence of mixed and, at times, highly polarized consumer opinions about Chipotle as a company, and the brand's "Food with Integrity" campaign. Research Question \#1 focused on general perceptions of the company. As a testament to the chain's wide popularity and positive reputation, many participants used words like "fresh," "ethical," "innovative," and "delicious" to describe Chipotle. In contrast, however, other participants (especially those with ties to agriculture) described Chipotle as "deceptive," "ridiculous," "hypocritical," and "unethical." Arguably, Chipotle's longstanding marketing approach has been to intentionally adopt an "offensive" messaging strategy that negatively depicts much of the agriculture business while proactively positioning the company as distinct, separate from, 


\section{Gikerson et al.: Farmed and Dangerous? A Case Study of Chipotle's Branded Entertai}

and more ethical than the rest of the food industry. Chipotle has built its brand by highlighting to consumers' negative aspects of the industrial food system while aligning itself with more positive notions of animal welfare protection and environmental advocacy.

Research Questions \#2 and \#3 specifically considered Chipotle's unique approach of using satirical and humorous branded entertainment content to market to consumers, and explored differences in how the messaging strategy in Farmed and Dangerous was perceived by consumers with varied levels of exposure and affiliation to the agriculture industry. Findings showed strong evidence of anger toward the company among members of the agriculture community, which is ostensibly one of Chipotle's key stakeholder populations. Participants affiliated with agriculture conveyed feelings of being offended, betrayed and personally attacked by Chipotle's marketing, with many participants seeming to adopt a defensive, "us against them," adversarial stance toward the company. What perhaps remains to be seen is whether this strategy, which has arguably done significant damage to Chipotle's relationship with the agriculture community, will have any long-term negative impact on the company's broader reputation or profitability. Many participants in the research conveyed strong positive attitudes toward the brand, and demonstrated little to no concern with how Chipotle satirically depicted agriculture in its marketing. Considering the general public's support for Chipotle's "Food with Integrity" message, including the satirical branded entertainment content examined here, angering and alienating farmers may do minimal harm to the company's broader success and, in fact, the divisive strategy may even serve to boost the brand's overall popularity.

It is interesting to note Chipotle's use of humor and satire within the Farmed and Dangerous series to convey its critical messages toward practices in the agriculture industry, as the inherent ambiguity and lightness of tone of satire allows the company to make negative claims about "big agriculture" without ever needing to be overly specific or forced to substantiate its criticisms of the industry. In a 2014 USA Today article following the launch of the series, Chipotle's director of communications Chris Arnold is quoted describing the comedy series as an "effective tool" to engage and educate consumers who aren't paying attention to issues in the food industry, predicting that the brand's strategy of helping people to "understand food and where it comes from" would pay dividends for the company (Doering, 2014). Reflecting the findings of this research, however, the same article also discusses multiple farmers and agriculture groups upset that the Farmed and Dangerous series portrayed an "unrealistic picture" of farming — and quotes an lowa farmer as objecting "to Chipotle's bullying tactics 'that pick on someone and knock them down' to stoke demand for their products" (Doering, 2014). Another farmer in the article accused Chipotle of "using fear and twisting the truth," as part of its marketing and advertising strategy, a perspective shared by several participants in this study. The article quotes Arnold, the Chipotle executive, rejecting this notion, arguing: "the industrial ag folks tend to read it (Chipotle's marketing) as attacks on them or criticism of them. It's never our intention to produce things where that is the aim" (Doering, 2014).

As a case study, this research shows evidence that Chipotle's marketing tactics have fostered salience of a conflict or battle frame between the general food-consuming population and members of the ag community who work to grow the public's food. An ethical discussion regarding Chipotle's "Food with Integrity" campaign could be held, considering so many members of the ag community consider the company's efforts to be deceptive, manipulative, and deceitful. However, it could also be argued that due to the satirical (and therefore ambiguous) nature of a series like Farmed and Dangerous, members of the ag community are misinterpreting the series' exaggerated depictions of the industry-and failing to see the humor within the satire. Like many messages, branded satirical content may leave audiences-from both sides of the issue-with the unfortunate tendency to only see what they want to see.

Chipotle's brand and reputation for food quality suffered significant damage during the fall and winter of 2015, following a series of high-profile food safety issues related to E.coli and norovirus outbreaks. It is important to note that the research reported in this study was conducted before these events occurred and, therefore, consumer responses today would likely vary from those who participated in this study. It is interesting to consider, however, that the recent challenges facing Chipotle's reputation have not gone unnoticed by the agriculture community. Writing about the company's food safety and public relations issues in a January 2016 commentary appearing on Beef Magazine's website, a rancher 
Journal of Applied Communications, V ol. 100, Iss. 3 [2016], Art. 11

acknowledged feelings of "schadenfreude" toward Chipotle's struggles: "For those of us who took exception to their anti-meat, anti-mainstream agriculture messages, it is hard to have much sympathy for their mistakes and problems" (Marshall, 2016, para. 3). While any headlines of food safety issues do harm to the broader image of the food industry, in this case it is evident some within the agriculture community were not sad to witness Chipotle facing its own public image challenges.

Furthermore, Chipotle and its "Food with Integrity" campaign have seemingly become a political lightning rod and target within the broader, often partisan, debates about healthy foods, humane animal treatment, and environmental sustainability issues. In September 2015, a website titled www.chubbychipotle.com was launched, along with a full-page newspaper ad appearing in major U.S. newspapers, which declared Chipotle to be "fast food hypocrites" and outlined ways in which the company's food is fattening and unhealthy and "its marketing is highly unscientific and harms animal welfare" (Chubby Chipotle, 2016). The website and newspaper ads were created by the "libertarian leaning" group The Center for Consumer Freedom (Fickenscher, 2015), a Washington D.C. non-profit that describes itself as working to promote "personal responsibility and consumer choice" (Consumer Freedom, n.d.). In November of 2015, the same group also ran full-page ads with the headline, "You Can't Spell 'Chipotle' without 'E-coli'" and statements that described Chipotle as "Food with Deception" (Wohl, 2015). An AdAge article written about the Center for Consumer Freedom's campaign against Chipotle reported the group does not divulge the identities of its funding sources, and that the organization only "says it is funded by undisclosed restaurants and food companies" (Wohl, 2015). Other news outlets have reported that the group has received funds in the past from Philip Morris, fast food chains Wendy's and White Castle, and Tyson Foods, among others (Fickenscher, 2015). The aggressiveness of the "Chubby Chipotle" campaign shows evidence that the burrito chain and its marketing has fostered enemies not just among members of the ag industry, but conservative players in the national political sphere as well.

This research serves in part as response to recent calls by scholars to address gaps in the literature related to how organizations strategically use online content for relationship-building efforts and improved understanding of how publics respond to marketing content on social media platforms (Saxon and Waters, 2014). Findings from this study offer new insight into the ways in which audiences and consumers react to and interpret advertising and marketing messages about food and agricultural production issues. While Chipotle's "Food with Integrity" message has drawn the ire of industry and political groups, the broader strategy has arguably been effective among consumers since it was first used as the title of the company's mission statement in 2001 (Maze, 2015). This research also helps to raise new questions about the implications, risks and ethical considerations for companies considering the use of similar marketing strategies and tactics. Agriculture, marketing and communication professionals should fully explore these considerations when choosing whether or not, or how to implement similar campaigns.

Future success of Chipotle's marketing strategy, and the impact of the company's food safety issues, will continue to help illuminate some of these issues. The resonance of Chipotle's "Food with Integrity" message, and the company's overall brand promise, have likely been eroded due to the extended 2015 health scare episodes. A January 2016 article reported that Chipotle's sales were down dramatically and that the company's stock value had decreased by 31 percent since the chain's first reported E.coli incident the previous fall (Little, 2016). The same piece quoted industry analysts arguing that the positive "halo" Chipotle had previously enjoyed related to perceptions of its food quality and integrity image may be gone forever as the company has reeled from the negative headlines and been forced to adopt more traditional fast food preparation techniques in an effort to improve food safety (Little, 2016). Food marketers and ag communication professionals alike can gain valuable lessons from Chipotle, as they consider the continued portrayal of the agriculture industry within marketing and advertising campaigns. 


\section{Gikerson et al.: Farmed and Dangerous? A Case Study of Chipotle's Branded Entertai}

\section{REFERENCES}

AdAge.com. (2013, September 13). Chipotle paints bleak portrait of Big Food in short film and game. AdAge.com. Available at http://adage.com/

Allen, K. (2015, January 19). How Chipotle's pork shortage is a PR win. PR Daily. Available at http://www.prdaily.com/

Barrett, R. (2014, February 22). Chipotle's 'Farmed and Dangerous' misleads viewers, farming groups say. The Milwaukee Journal Sentinel. Available at http://www.jsonline.com/

Breen, T.H. (2005). The marketplace of revolution: How consumer politics shaped American independence. Oxford, England: Oxford University Press.

Chipotle Adverts. (n.d.) Chipotle adverts and commercials archive. Advertolog.com. Available at http://www.advertolog.com/

Chipotle Hits. (2014, January 27). Chipotle hits Hulu with debut of satirical series 'Farmed and Dangerous'. AdAge. Available at http://adage.com/

Chipotle Mexican Grill: Food with Integrity. What is food with integrity? (2015, January 1). Available at http://www.chipotle.com/

Chipotle Mexican Grill: Food with Integrity. People are people too. (2015, January 1). Available at http://www.chipotle.com/

Choi, C. (2015, January 6). Chipotle served with a subpoena as criminal investigation of norvirus outbreak opens. The Star Tribune. Available at http://www.startribune.com/

Coloribus. (2015). Chipotle: "Farmed and Dangerous Fiction Entry" Online advert by PIRO New York, Media-Storm. (n.d.). Coloribus Creative Advertising Archive. Available at http://www.coloribus.com/

Consumer Freedom. (n.d.) The Center for Consumer Freedom: Promoting personal responsibility and protecting consumer choice. Available at https://www.consumerfreedom.com/

Czaplewski, A., Olson, E.M., \& McNulty, P. (2014, March). "Going Green Puts Chipotle in the Black." Marketing News. American Marketing Association. Available at https://www.ama.org.

Doerfert, D.L. (2011). National research agenda: American Association of Agricultural Education's research priority areas for 2011-2015. Lubbock, TX: Texas Tech University, Department of Agricultural Education and Communications.

Doering, C. (2014, March 3). Chipotle's farm satire upsets agriculture industry. USA Today. Available at http://www.usatoday.com/

Farmed and Dangerous: Chipotle Original Series. (n.d.). Available at http://www.farmedanddangerous.com/

Fickenscher, L. (2015, September 4). Who's behind ad campaign against Chipotle? The New York Post. Available at http://nypost.com/

Fox, M. (2015, November 11). Chipotle to reopen Washington, Oregon outlets after E. Coli outbreak. NBC News. Available at http://www.nbcnews.com/

Holbert, R.L., Tchernev, J.M., Walther, W.O., Esralew, S.E., \& Benski, K. (2013). Young voter perceptions of political satire as persuasion: A focus on perceived influence, persuasive intent, and message strength. Journal of Broadcasting \& Electronic Media, 57(2), 170-186. doi:10.1080/08838151.2013.787075

Holt, J.A., \& Cartmell, D. (2013). Consumers' perceptions of the agricultural industry before and after watching the film Food, Inc. Journal of Applied Communication, 97 (3), 45-56.

Hudson, S., \& Hudson, D. (2006). Branded entertainment: a new advertising technique or product placement in disguise? Journal of Marketing Management, 22(5-6), 489-504. doi:10.1362/026725706777978703

LaMarre, L., Landreville, K.D., \& Beam, M.A. (2009). The irony of satire: political ideology and the motivation to see what you want to see in the Colbert Report. International Journal of Press/Politics, 14(2), 212-231. doi:10.1177/1940161208330904

LaMarre, H.L., Landreville, K.D., Young, D., \& Gilkerson, N. (2014). Humor works in funny ways: Examining satirical tone as a key determinant in political humor message processing. Mass Communication and Society, 17(3), 400-423. doi:10.1080/15205436.2014.891137

Lee, H., \& Kwak, N. (2014). The affect effect of political satire: Sarcastic humor, negative emotions, and political participation. Mass Communication and Society, 17(3), 307-328. doi:10.1080/15205436.2014.891133 
Little, K. (2016, January 6). Chipotle 'halo' might be gone forever: analyst. CNBC.com. Available at http://www.cnbc.com/

Lutz, A. (2015, January 16). Chipotle's pork shortage reveals an underlying problem with the business. Business Insider. Available at http://www.businessinsider.com/

Marshall, T. (2016, January 7). A rancher's thoughts on Chipotle and the Oregon standoff. Beef Magazine. Available at http://beefmagazine.com/

Maze, J. (2015, September 14). Chipotle's mission and tactics revolutionize restaurant industry: The fast-casual chain was the first major brand to market itself with a humane, sustainability message. Nation's Restaurant News. Available at https://business.highbeam.com/

Munarriz, R. (2015, April 28). What is the secret of Chipotle's success? DailyFinance.com. Available at http://www.dailyfinance.com/

Nath, T. (2015, March 13). Shake Shack and Chipotle: A financial comparison. Investopedia.com. Available at http://www.investopedia.com/

Nudd, T. (2014, February 4). Chipotle's next tasty marketing gambit: A scripted satire online. AdWeek. Available at http://www.adweek.com/

Peterson, H. (2015, January 14). The reason behind Chipotle's sudden pork shortage. Business Insider. Available at http://www.businessinsider.com/

Ragas, M.W., \& Roberts, M.S. (2009). Communicating corporate social responsibility and brand sincerity: A case study of Chipotle Mexican Grill's 'Food with Integrity' program. International Journal of Strategic Communication, 3(4), 264-280. doi:10.1080/15531180903218697

Ragas, M.W., \& Roberts, M.S. (2009). Agenda setting and agenda melding in an age of horizontal and vertical media: A new theoretical lens for virtual brand communities. Journalism \& Mass Communication Quarterly, 86(1), 45-64. doi:10.1177/107769900908600104

Saxton, G.D., \& Waters, R.D. (2014). What do stakeholders like on Facebook? Examining public reactions to nonprofit organizations' informational, promotional, and community-building messages. Journal of Public Relations Research, 26(3), 280-299. doi:10.1080/1062726x.2014.908721

Scherer, J. (2015, January 16). Dude, they found your carnitas: Chipotle solves its pork crisis. Take Part Magazine. Available at https://www.takepart.com/

Shrum, L.J. (Ed.). (2012). The psychology of entertainment media: Blurring the lines between entertainment and persuasion. New York, NY: Taylor \& Francis.

Solomon, B. (2014, October 20). Chipotle continues explosive growth in the burrito bull market. Forbes.com. Available at http://www.forbes.com/

Spar, D.L., \& La Mure, L.T. (2003). The power of activism: Assessing the impact of NGOs on global business. California Management Review, 45(3), 78-101.

Stein, L. (2015, March 27). PR agencies and marketing embrace Hollywood. PR Week. Available at http://www.prweek.com/

Strauss, A., \& Corbin, J. (1998). Basics of qualitative research: Techniques and procedures for developing grounded theory. Thousand Oaks, CA: Sage.

Trotter, G. (2015, December 16). Chipotle CEO in newspaper ad: 'I am deeply sorry.' Chicago Tribune. Available at from http://www.chicagotribune.com/

Veil, S.R., Reno, J., Freihaut, R., \& Oldham, J. (2014). Online activists vs. Kraft foods: A case of social media hijacking. Public Relations Review, 41(1), 103-108. doi:10.1016/j.pubrev.2014.11.017

Wohl, J. (2015, November 4). Anti-Chipotle group takes out full-page ad on E.Coli. AdAge.com. Available at http://adage.com/

Yin, R.K. (2013). Case study research: Design and methods. Thousand Oaks, CA: Sage.

Yohn, D.L. (2014, March 14). How Chipotle changed American fast food forever. Fast Company. Available at http://www.fastcompany.com/

Young, A. (2014, March 3). Producing a TV series without showing a burrito, Chipotle takes a risk. AdAge.com. Available at http://adage.com/

Zarroli, J. (2016, January 5). After Chipotle outbreaks, will 'Food With Integrity' still resonate? National Public Radio. Available at http://www.npr.org/ 
Zhang, J., Sung, Y., \& Lee, W.N. (2010). To play or not to play: An exploratory content analysis of branded entertainment in Facebook. American Journal of Business, 25(1), 53-64. doi:10.1108/19355181201000005

\section{ABOUT THE AUTHORS}

Nathan Gilkerson (corresponding author), nathan.gilkerson@marquette.edu, Assistant Professor, Department of Strategic Communication, Diederich College of Communication, Marquette University, 1131 W. Wisconsin Ave, Milwaukee, WI 53233

Rebecca Swenson, boli0028@umn.edu, Assistant Professor of Agricultural, Food, and Natural Resource Communication, College of Food, Agricultural and Natural Resource Sciences (CFANS), University of Minnesota, 146 Ruttan Hall, 1994 Buford Ave., St. Paul, MN 55108

Betsy Anderson, andbets@umn.edu, Visiting Assistant Professor, School of Journalism and Mass Communication (SJMC), University of Minnesota, 111 Murphy Hall, 206 Church St. S.E., Minneapolis, MN 55455 